\title{
Аналіз впливу розміру газопарової бульбашки на процес гідратоутворення
}

\author{
Б. А. Кутний ${ }^{1}$, А. М. Павленко ${ }^{2, \bigotimes}$, Н. М. Абдуллах ${ }^{3}$ \\ 1,3 Полтавський національний технічний університет ім. Юрія Кондратюка, пр. Першотравневий, 24, м. Полтава, \\ 36011, Україна \\ ${ }^{2}$ Келецький технологічний університет (Politechnika Świętokrzyska), aleja Tysiąclecia Państwa Polskiego 7, 25-314 \\ Kielce, Polska \\ ORCID: ${ }^{1}$ 0000-0002-0548-7925, ${ }^{2}$ 0000-0002-8103-2578, ${ }^{3} 0000-0003-3922-0441$; Scopus ID: ${ }^{2} 12801813400$ \\ $\triangle$ e-mail: am.pavlenko@i.ua
}

\begin{abstract}
Запропонована математична модель, яка враховує інериійну та термодинамічну складові осциляції бульбашок, теплообмінні прочеси у рідині, теплообмін на границі бульбашки. Проведено дослідження динамічних характеристик газопарових бульбашок різних розмірів. Після виконаних розрахунків побудовано графіки зміни розміру бульбашки, ї̈ температури, швидкості руху, тиску парогазового середовища всередині бульбашки в часі. Встановлено, що кожен розмір бульбашок має свою частоту осцилячій. Розраховано швидкість гідратоутворення і встановлено, що вона набуває максимальних значень під час розігріву газового середовища всередині бульбашки. Поступово у в'язкій рідині осцилячії затухають і процес гідратоутворення підтримується за рахунок відведення теплоти у зовнішні шари рідини. За термодинамічними характеристиками поверхні контакту рідкої та газоподібної фаз визначено кількість утвореного газового гідрату. Результати досліджень можуть застосовуватися для оптимізачї різноманітних технологічних прочесів, пов'язаних з кипінням, спученням матеріалів, утворенням газових гідратів та кавітацією у рідині.
\end{abstract}

Ключові слова: Математична модель; Бульбашка; Теплообмін; Газовий гідрат; Тиск; Температура.

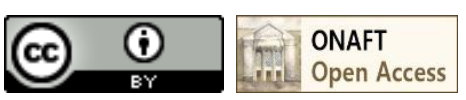

\section{1. Вступ}

Транспортування та зберігання природного газу зручно здійснювати коли він перебуває у формі газового гідрату. Технологічно утворення газових гідратів відбувається в умовах розчинення газових бульбашок у воді за певних термобаричних умов. Сам процес утворення газового гідрату відбувається на поверхні осцилюючої бульбашки. В ході осциляції відбувається дуже швидка зміна термодинамічних параметрів системи «газопарова бульбашка - рідина». Дослідження динаміки цього процесу дозволяє визначити найбільш впливові фактори та оптимізувати технологічний процес отримання газових гідратів. Пряме спостереження процесів утворення газових гідратів є складною інженернотехнічною задачею: високий тиск (до $20 \mathrm{MПа),} \mathrm{малі}$ розміри бульбашок $(10-5 \div 10-7$ м) та висока швидкість їх осциляції (приблизно 10-5 с). Простішим шляхом $є$ математичне моделювання процесу гідратоутворення.

\section{2. Огляд останніх джерел досліджень i публікацій}

Для аналізу динаміки росту парових бульбашок широко застосовують рівняння Релея-Плассета $[1,2,3]$.
Для визначення тиску всередині парової бульбашки часто застосовують рівняння Клапейрона-Клаузіуса [4, 5], або вважають процес адіабатним [6]. На думку інших вчених, процеси всередині осцилюючої бульбашки не обмежуються лише фазовим переходом чи відсутністю теплообміну на поверхні бульбашки. В роботі [7] математична постановка задачі більш повна. Крім рівняння Релея-Плассета вона містить рівняння Ван-дерВаальса для визначення тиску всередині газопарової бульбашки та дозволяє розрахувати температуру газів всередині бульбашки на основі першого закону термодинаміки. Також математична модель доповнена переносом теплоти та маси через границю бульбашки. Проте дана математична модель розрахована на бульбашки, які утворюються в результаті кавітації і всередині яких знаходиться сильно розріджений газ. Фазові переходи в рідині також в цій моделі не враховано.

\section{3. Виділення не розв'язаних раніше частин загальної проблеми}

Для моделювання процесів утворення газових гідратів необхідно врахувати можливість розчинення газів бульбашки в рідині з одночасним фазовим переходом рідини у тверду фазу (газовий гідрат). Цей процес ви- 
значається швидкістю тепло- та масообмінних процесів біля поверхні бульбашки, які у свою чергу залежать від температури та тиску газопарової суміші всередині бульбашки. Внаслідок гідратоутворення теплофізичні характеристики рідини на границі з бульбашкою також можуть суттєво змінюватися. Таким чином, для коректної постановки задачі необхідно адекватно врахувати комплекс взаємопов'язаних між собою механічних та термодинамічних процесів, які протікають в обмеженому об'ємі на високій швидкості.

\section{4. Постановка завдання}

Метою даної роботи є створення математичної моделі динаміки парової бульбашки, яка дозволить отримувати достовірну інформацію про іiі термодинамічні характеристики під час росту чи стискання. У загальному вигляді математична модель повинна містити наступні складові: модель кінетики газової бульбашки у в'язкій рідині; модель термодинамічних процесів всередині газопарової бульбашки; модель тепло- і масообмінних процесів на границі бульбашки; моделювання фазових переходів в рідині з утворенням льоду чи газового гідрату; моделювання теплообмінних процесів у рідині, що оточує бульбашку.

\section{5. Основний матеріал і результати}

Для розробки математичної моделі газопарової бульбашки в рідині застосовано наступні спрощуючі припущення: газопарова бульбашка має сферичну форму; рідина є в'язкою та нестисливою; всередині газопарової бульбашки знаходиться суміш газу та парів рідини, маса яких може змінюватися в результаті масообмінних процесів на границі бульбашки; газ та пари рідини в середині бульбашки розглядаються як реальний газ (3 урахуванням Ван-дер-Ваальсових сил) [7].

Швидкість руху рідини $(\dot{R})$ на границі бульбашки можна визначити шляхом інтегрування відомого рівняння Релея-Плассета [1]. Загалом, математична модель термодинамічних процесів газопарової бульбашки містить наступні рівняння:

$$
\begin{gathered}
\frac{d \dot{R}}{d \tau}=\frac{P_{B(\tau)}-P_{\infty}}{\rho_{r} R}-\frac{1.5}{R} \dot{R}^{2}-\frac{4 \mu_{r}}{\rho_{r} \cdot R^{2}} \dot{R}-\frac{2 \sigma_{r}}{\rho_{r} \cdot R^{2}}, \\
\frac{d R}{d \tau}=\dot{R}, \\
P_{B}=P_{g}+P_{p}, \\
P_{g}=\frac{R_{\mu} T}{\frac{\mu_{g}}{\rho_{g}}-b_{g}}-\rho_{g}^{2} \frac{a_{g}}{\mu_{g}^{2}}, \quad P_{p}=\frac{R_{\mu} T}{\mu_{p}}-b_{p} \rho_{p}^{2} \frac{a_{p}}{\rho_{p}^{2}}, \\
\frac{d \rho_{g}}{d \tau}=\frac{3}{R}\left(-\rho_{g} \frac{d R}{d \tau}\right), \quad \frac{d \rho_{p}}{d \tau}=\frac{3}{R}\left(-\rho_{p} \frac{d R}{d \tau}\right), \\
\frac{d T}{d \tau}=\frac{3}{R\left(c_{g} \rho_{g}+c_{p} \rho_{p}\right)}\left[q-P_{B} \frac{d R}{d \tau}\right], \\
{\left[\left(\frac{1}{6} \rho_{g} \bar{v}_{g(T)}+\Delta I_{g}\right) c_{g}+\left(\frac{1}{6} \rho_{p} \bar{v}_{p(T)}+\Delta I_{p}\right) c_{p}\right]\left(T_{(R, \tau)}-T\right)}
\end{gathered}
$$

$$
\begin{gathered}
\bar{v}_{g(T)}=\sqrt{8 R_{\mu} T / \mu_{g} \pi} \text { та } \bar{v}_{p(T)}=\sqrt{8 R_{\mu} T / \mu_{p} \pi}, \\
\Delta I_{g}=-\frac{D_{g} P_{g}}{R \Gamma}, \\
\Delta I_{p}=\frac{2 D_{p}}{R}\left(\rho_{p}^{*}-\rho_{p}\right), \\
\Delta I_{g g}=\frac{2 D_{g}}{R}\left(\rho_{g g}^{*}-\rho_{g}\right),
\end{gathered}
$$

$$
\begin{gathered}
\rho_{g}^{*}=\frac{\mu_{g}}{R_{\mu} T} \frac{\mu_{p}}{P_{g}^{*}+\left(\rho_{g}^{*}\right)^{2} \frac{a_{g}}{\mu_{g}^{2}}+b_{g}}, \rho_{p}^{*}=\frac{R_{\mu} T}{P_{p}^{*}+\left(\rho_{p}^{*}\right)^{2} \frac{a_{p}}{\mu_{p}^{2}}+b_{p}}, \\
P_{g(T)}^{*}=P_{S g} \exp \left[\frac{r_{g} \mu_{g}}{R_{\mu}}\left(\frac{1}{T_{S g}}-\frac{1}{T_{(R, \tau)}}\right)\right], \\
P_{p(T)}^{*}=P_{S p} \exp \left[\frac{r_{p} \mu_{p}}{R_{\mu}}\left(\frac{1}{T_{S p}}-\frac{1}{T_{(R, \tau)}}\right)\right],
\end{gathered}
$$

$$
\begin{gathered}
\frac{\partial\left(\rho_{r} c_{r} T_{(x, \tau)}\right)}{\partial \tau}+\dot{R} \frac{\partial\left(\rho_{r} c_{r} T_{(x, \tau)}\right)}{\partial x}=\frac{1}{x^{2}} \frac{\partial}{\partial x}\left(\lambda_{r} x^{2} \frac{\partial T_{(x, \tau)}}{\partial x}\right) \\
q_{v(x, T)}=r_{g} \frac{\partial}{\partial \tau}\left(\frac{\partial m_{g g}}{\partial V}\right)+r_{p} \frac{\partial}{\partial \tau}\left(\frac{\partial m_{p}}{\partial V}\right), \\
-\frac{\partial\left(\lambda_{r} T\right)}{\partial x}(x=R, \tau)=-q \\
T_{(x, \tau=0)}=T_{0},
\end{gathered}
$$

де $\dot{R}$ - швидкість руху рідини на границі бульбашки, м/c; $\tau$ - час, с; $P_{B(\tau)}-$ тиск парогазової суміші всередині бульбашки, Па; $P_{\infty}-$ тиск рідини, Па; $\rho_{r}-$ густина рідини, кг $/ \mathrm{M}^{3} ; \mu_{r}$ - динамічна в'язкість рідини, Па·с; $\sigma_{r}-$ коефіцієнт поверхневого натягу на межі рідинагаз, Н/м; $P_{g}$ - парціальний тиск газу, Па; $P_{p}$ - парціальний тиск водяних парів, Па; $\rho_{g}, \rho_{p}-$ густина відповідно газу та пари, кг/м ${ }^{3} ; R_{\mu}=8314$ - універсальна газова постійна, Дж/(кмоль·К); $\mu_{g}$ - молекулярна маса газу, кг/кмоль; $\mu_{p}$-молекулярна маса парів рідини, кг/кмоль; $T$ - температура суміші газів в бульбашці, К; $a_{g}, a_{p}$ - постійна Ван-дер-Ваальса відповідно для газу

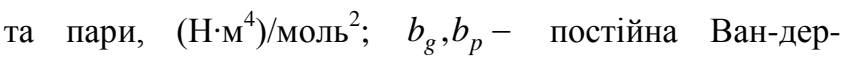
Ваальса відповідно для газу та пари, м ${ }^{3} /$ моль; $c_{g}, c_{p}-$ масова теплоємність парів газу та пари, Дж/(кг $\left.{ }^{\circ} \mathrm{C}\right)$; $\bar{v}_{g(T)}, \bar{v}_{p(T)}-$ середньоарифметична швидкість теплово- 
го руху молекул газу та пари, м/с; $\Delta I_{g}-$ питома швидкість масообміну газу під час дифузії у воду, кг/( $\left.\mathrm{M}^{2} \cdot \mathrm{c}\right)$; $\Delta I_{p}$ - питома масова швидкість конденсації водяних

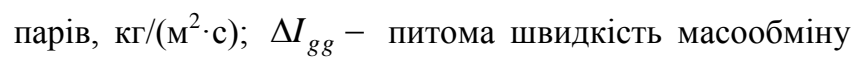
газу під час утворення гідрату, кг/( $\left.\mathrm{M}^{2} \cdot \mathrm{c}\right) ; \Gamma-$ константа

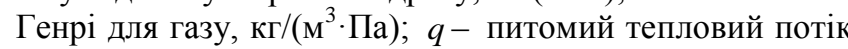
біля поверхні бульбашки, Вт/м²; $T_{(R, \tau)}$ - температура поверхні бульбашки, ${ }^{\circ} \mathrm{C} ; D_{p}, D_{g}-$ коефіцієнти дифузії відповідно пару та газу, ${ }^{2} / \mathrm{c} ; \rho_{g}^{*}, \rho_{p}^{*}-$ густина відпові-

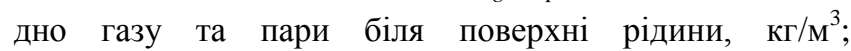
$P_{g}^{*}, P_{p}^{*}$-парціальний тиск газу та водяних парів над поверхнею рідини, Па; $r_{p}, r_{g}$ - теплота фазового переходу вода-пар та гідрат-газ, Дж/кг; $m_{g g}, m_{p}-$ маса відповідно газу, який переходить у форму гідрату та водяної пари, що конденсується, кг; $c_{r}-$ теплоємність рідини, Дж/(кг $\left.{ }^{\circ} \mathrm{C}\right) ; \lambda_{r}-$ теплопровідність рідини,

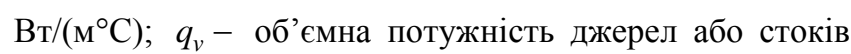
теплоти, Вт/м ${ }^{3} ; T_{0}$ - початкова температура рідини, ${ }^{\circ} \mathrm{C}$.

В результаті фазовоперехідних процесів на границі бульбашки рідина може змінювати свої теплофізичні характеристики $\left(\lambda_{r}, \rho_{r}, c_{r}\right)$. Об'ємні джерела теплоти дозволяють враховувати фазові переходи у рідкому середовищі.

Для утворення гідрату необхідне виконання ряду умов: парціальний тиск газу повинен перевищувати мінімальний тиск гідратоутворення за даної температури; температура гідратоутворення (фазового переходу) повинна бути рівною функціональній залежності для гідратоутворення за даного парціального тиску. Маса гідрату визначається відведенням теплоти фазового переходу 3 області гідратоутворення. Інтенсивність об'ємних джерел теплоти для процесу гідратоутворення (або його розкладу) прийнята лінійно пропорційною різниці температур поверхні фазового переходу та температури рівноважного стану гідрату.

Систему рівнянь (1)-(17) можна розв'язувати за допомогою цифрових методів, наприклад методу РунгеКутта 4-го порядку [8, 9]. За запропонованою математичною моделлю була складена комп'ютерна програма «RELEY5» і виконано дослідження поведінки бульбашок метану різного розміру ( радіусом $2,0,5,0,1,0,05$, та 0,01 мм) за таких вихідних умов. Нехай бульбашка метану з домішками водяної пари і початковою температурою $0^{\circ} \mathrm{C}$ попадає у воду 3 температурою $+5^{\circ} \mathrm{C}$. Визначимо вплив розміру бульбашки на швидкість процесу гідратоутворення. Для цього було виконано розрахунки термодинамічних характеристик бульбашок різного розміру при тиску води, достатньому для гідратоутворення. Результати розрахунку наведено на рисунках 1-6.

Для бульбашки 3 початковим радіусом 0,1 мм. результати розрахунку іiі розміру та маси утвореного гідрату з часом показано на рисунку 1. Очевидно, що найбільш інтенсивне гідратоутворення співпадає 3 найбільш інтенсивним збільшенням розміру бульбашки. Під час коливального процесу ріст кількості гідрату змінюється періодами його дисоціації. Фаза росту співпадає зі збільшенням радіусу бульбашки. Після затухання коливального процесу розмір бульбашки стабілізується, проте гідрат продовжує утворюватися.

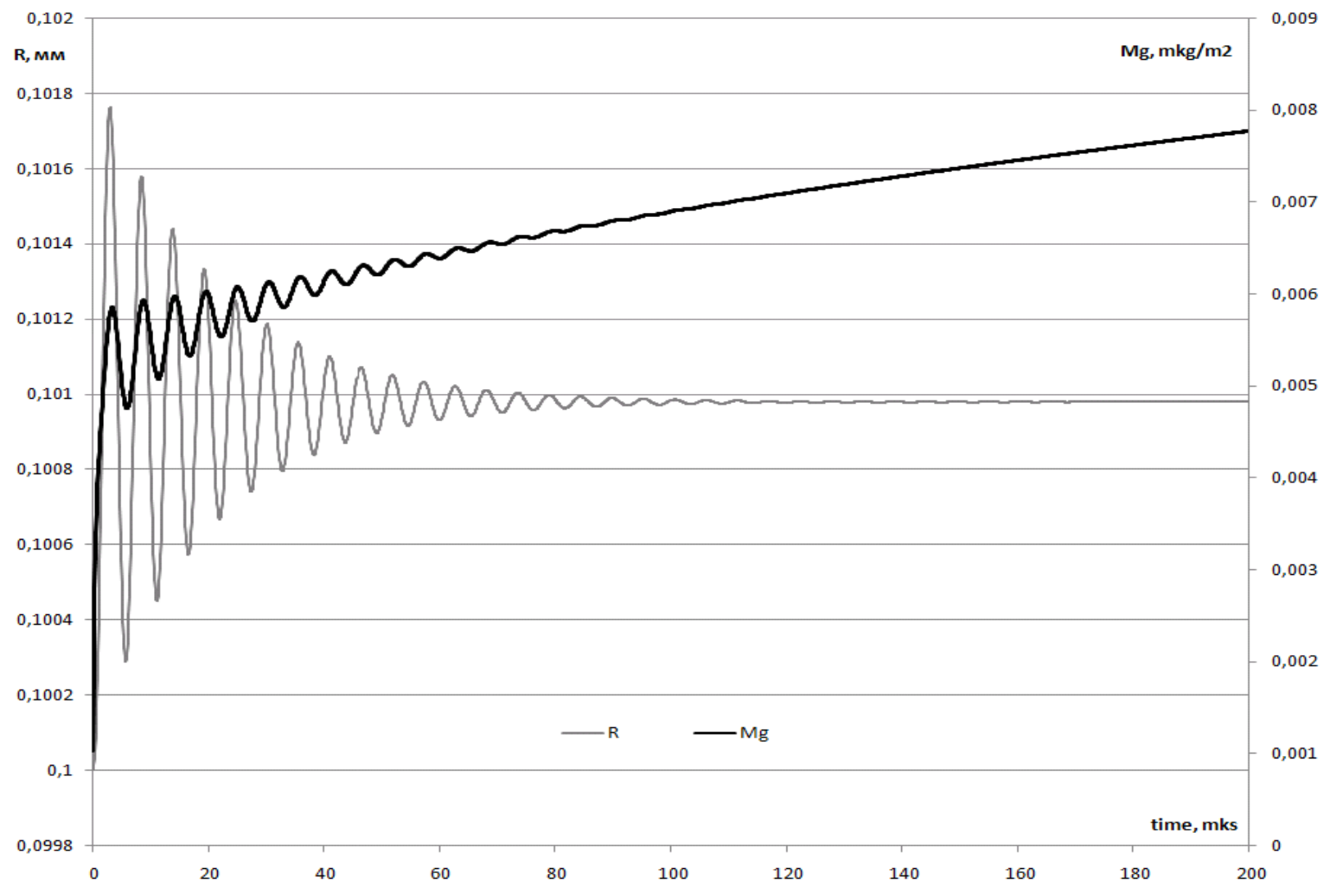

Рисунок 1 - Зміна радіусу бульбашки та питома маса утвореного гідрату 
Аналізуючи рисунок 2 можна виділити три характерні області температур бульбашки: область прогрівання (від 0 до $+5^{\circ} \mathrm{C}$ ), область затухаючих осциляцій та стаціонарну область. Бульбашки маленьких розмірів прогріваються дуже швидко і ця область на графіку майже не помітна. Область прогрівання стає відчутною лише для порівняно великих бульбашок. За рахунок інтенсивного відведення теплоти саме в цій області спостерігається найбільш висока швидкість гідратоутворення, проте вона має малу тривалість і тому кількість утвореного гідрату є невеликою. Для усіх розмірів бульбашок при заданих початкових умовах амплітуда коливання температури парогазової суміші не перевищує $0,5^{\circ} \mathrm{C}$. Логарифмічний декремент затухання для бульбашок радіу- сом 0,01 мм становить 0,32 ; для бульбашок радіусом 0,05 мм - 0,26; для бульбашок радіусом 0,1 мм - 0,25. Після завершення коливального процесу температура парогазового середовища бульбашки практично не змінюється.

На відміну від кавітаційних процесів, де швидкості руху стінки бульбашки сягають сотень метрів за секунду, бульбашки з газом мають значно нижчі швидкості руху стінки (рисунок 3). Початкова швидкість руху визначається початковими умовами і приблизно рівна для бульбашок різного розміру. 3 часом швидкість затухає (за рахунок втрат енергії на тертя та теплообмін 3 навколишнім середовищем) тим швидше, чим менший розмір бульбашки.

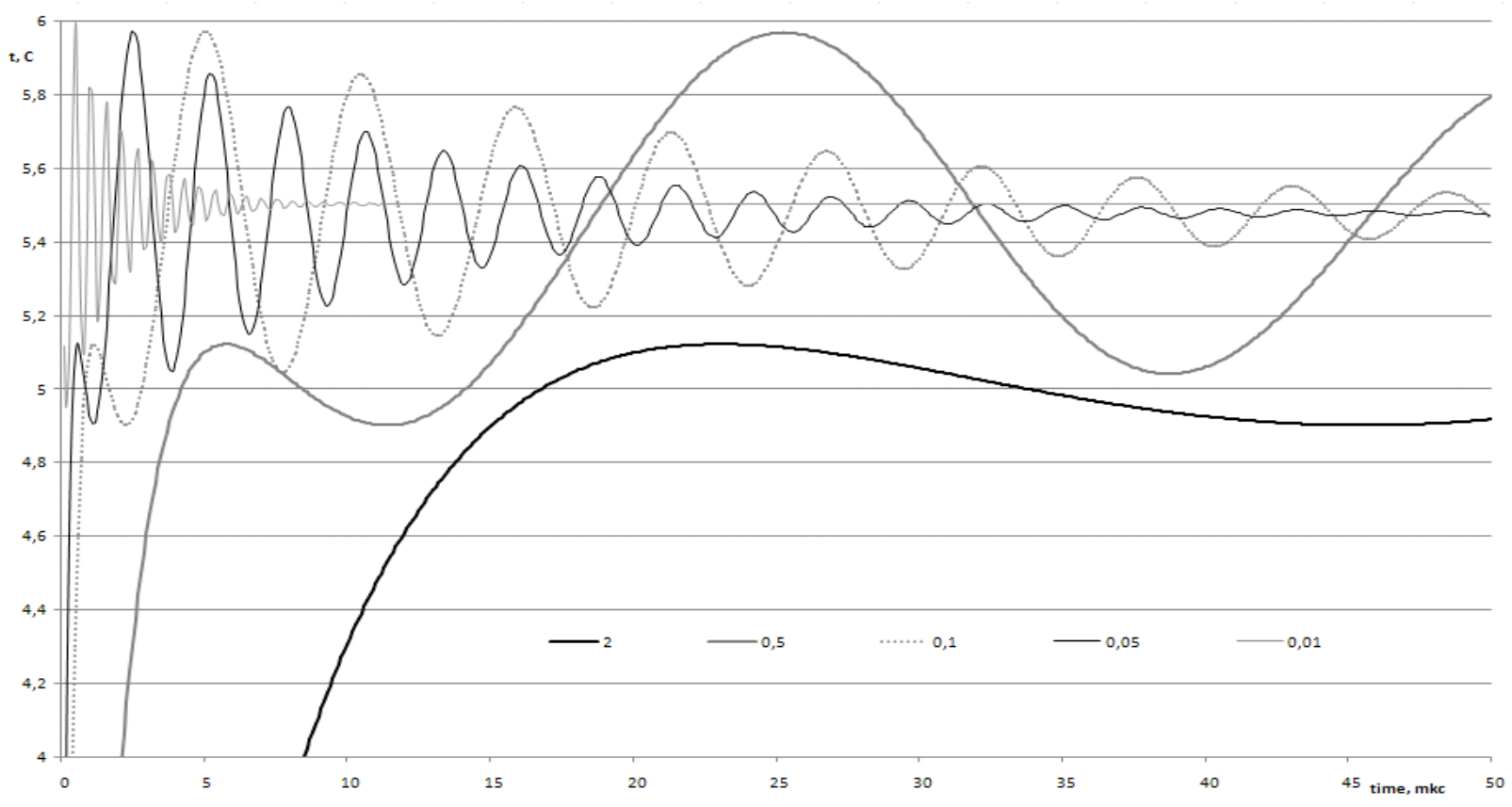

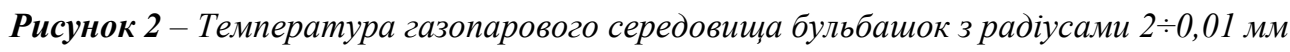

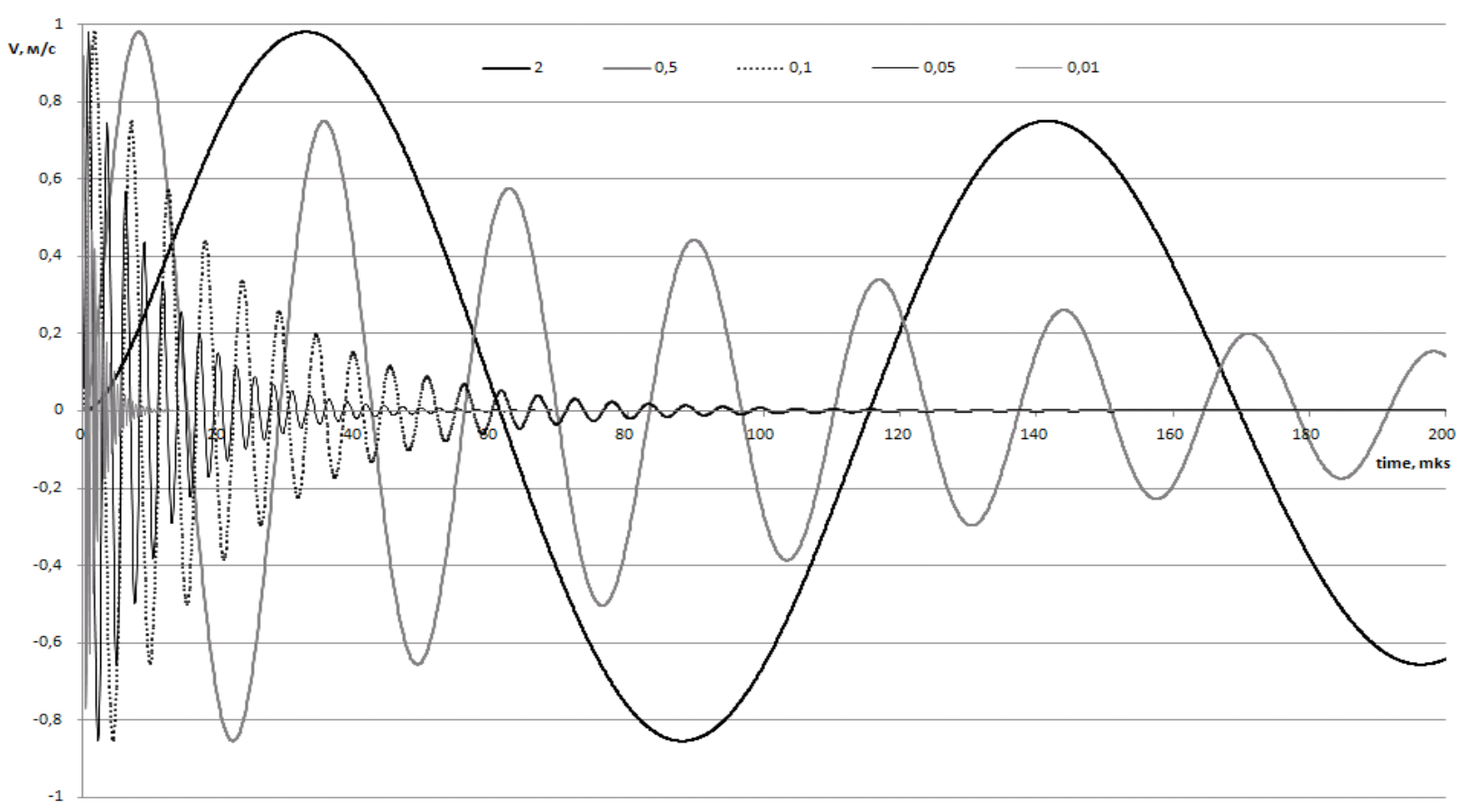

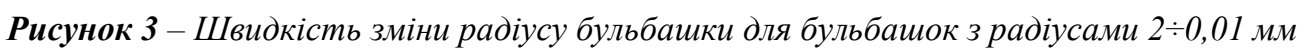


Результати розрахунку з утворення гідрату на поверхні бульбашок різного розміру, але однакового загального об'єму показані на рисунку 4. Аналіз отриманих залежностей вказує на значний вплив двох факторів на швидкість утворення гідрату: розмір бульбашок та часу. У бульбашок великих розмірів (радіус більше
0,5 мм) домінуючий вплив на гідратоутворення має ділянка початкового нагрівання бульбашки. Подальші осциляції бульбашки мало впливають на кількість утвореного гідрату. Мала загальна площа таких бульбашок теж не сприяє збільшенню кількості гідрату.

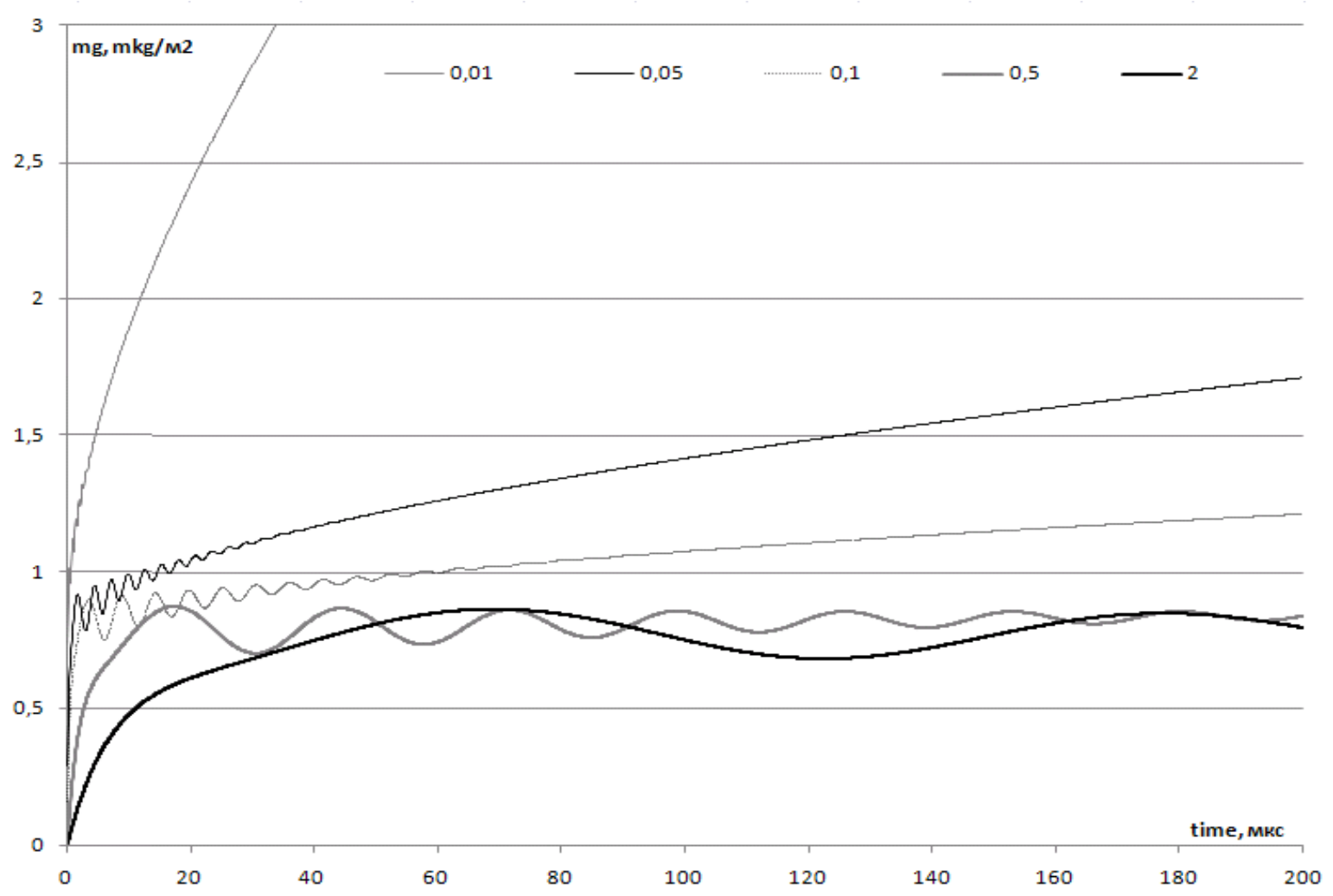

Рисунок 4 - Питома кількість гідрату, який утворюється на поверхні бульбашок різного розміру $(0,01$ мм, 0,05 мм, 0,1 мм, 0,5 мм, 2 мм)

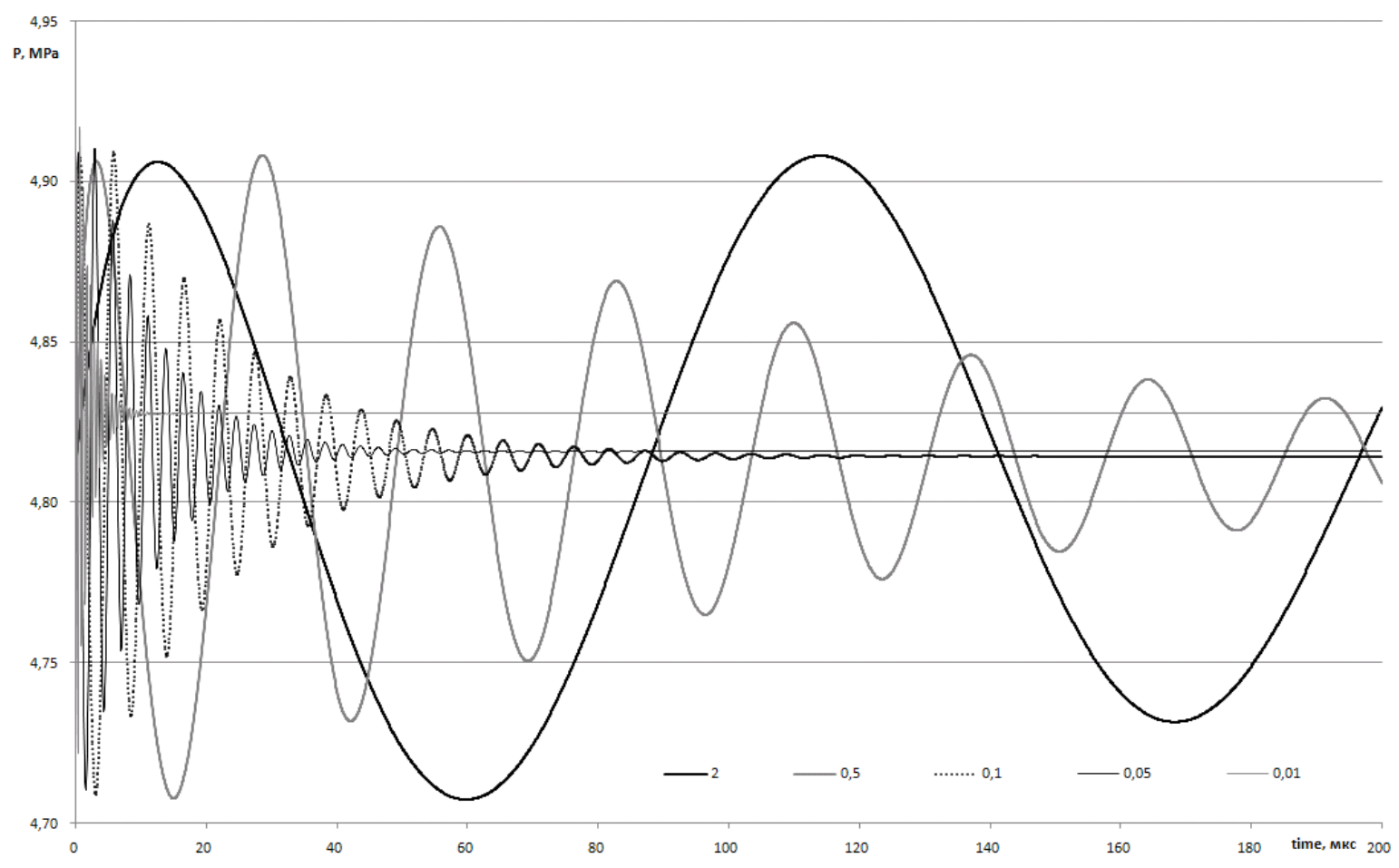

Рисунок 5 - Графіки зміни тиску газопарового середовища бульбашки 
Бульбашки середнього розміру (радіусом 0,10,05 мм) мають дві характерні ділянки гідратоутворення: ділянку початкового розігріву та ділянку теплообміну з навколишнім середовищем. За рахунок відведення теплоти у воду кількість утвореного гідрату поступово збільшується. Найбільша швидкість гідратоутворення характерна для бульбашок малого розміру (радіусом 0,01 мм та менше). Ділянка початкового розігріву тут дуже коротка і не відіграє значної ролі. Основна кількість гідрату утворюється в процесі теплообміну газу з водним середовищем.

Тиск в середині бульбашки є ще одним важливим фактором гідратоутворення (рисунок 5). Кожен розмір бульбашок має свою частоту осциляцій. Чим менші бульбашки, тим частота їх коливань буде більшою: $\mathrm{R}=2 \mathrm{mм}-\mathrm{f}=9,1$ кГц; $\mathrm{R}=0,5 \mathrm{mм}-\mathrm{f}=33$ кГц; $\mathrm{R}=0,1 \mathrm{мм}-\mathrm{f}=200$ кГц; $\mathrm{R}=0,05$ мм $-\mathrm{f}=400$ кГц; $\mathrm{R}=0,01 \mathrm{мм}-\mathrm{f}=2,0$ МГц. Початкова амплітуда коливань приблизно однакова для усіх бульбашок, проте коливання менших бульбашок затухають скоріше.

При однакових початкових температурних умовах середній тиск всередині менших бульбашок буде більший. Це явище, спричинене силами поверхневого натягу, також інтенсифікує процес гідратоутворення.

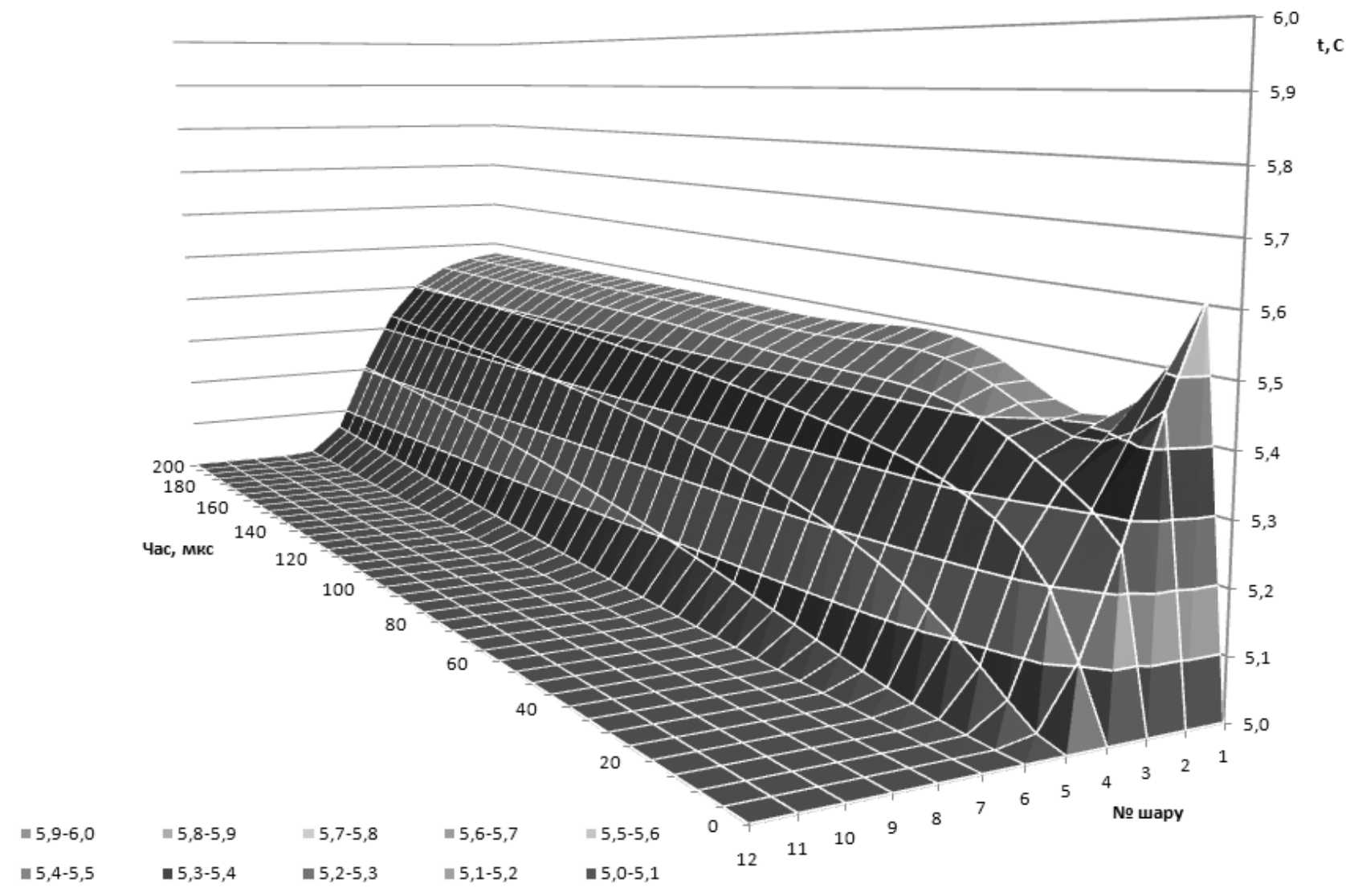

Рисунок 6 - Проникнення «теплової хвилі» у воду, яка оточує бульбашку з радіусом 0,1 мм

\section{6. Висновки}

Розроблено математичну модель для комплексного врахування впливу різноманітних факторів на термодинамічний стан осцилюючої газопарової бульбашки. На початку процесу гідратоутворення спостерігаються осциляції (затухаючі коливання) бульбашки. Пусковим механізмом для цих коливань $є$ різниця температур між газопаровим середовищем бульбашки та температурою гідратоутворення, яка визначається тиском середовища. Під час гідратоутворення відбувається локальне підвищення температури рідини, а потім за рахунок теплообміну і парогазового середовища бульбашки. Ріст температури газу призводить до збільшення тиску бульбашки і починається процес збільшення іiї діаметра. Ко- жен розмір бульбашок має свою частоту осциляцій. Поступово у в'язкій рідині осциляції затухають і процес гідратоутворення підтримується за рахунок відведення теплоти у зовнішні шари рідини. Під час початкового розігріву газу в бульбашці спостерігається максимальна швидкість гідратоутворення. 3 часом швидкість утворення гідратів зменшується.

\section{Література}

1. Кулінченко В. Р. Передумови створення математичної моделі - основні положення і рівняння руху Релея / В. Р. Кулінченко, В. Л. Зав'ялов, Т. Г. Мисюра // Наукові праці Національного університету харчових технологій. - 2007. - № 22. - С. 36-41. 
2. Ильмов Д. Н. Теплофизические процессы при сжатии парового пузырька в жидком углеводороде на основе гомобарической модели [Электронный ресурс]/ Д. Н. Ильмов, С. Г. Черкасов // Теплофизика высоких температур ГНЦ ФГУП «Центр Келдыша». - Москва, 2012. - Том 50, № 5 - С. 676-684. - Режим доступа: http://www.mathnet.ru/links/a96357749ddc8f7cc5ff3dcf53 c5493a/tvt396.pdf

3. Павленко А. М. Особенности управления процессами формирования структуры и свойств пористых тел/ А. М. Павленко, А. В. Кошлак // Металлургическая теплотехника, сборник научных трудов НМет АУ. Днепропетровск, 2008. - С. 211-220.

4. Шагапов В. Ш. К теории роста паровых пузырьков в метастабильной жидкости [Электронный ресурс] / В. Ш. Шагапов, В. В. Коледин // Теплофизика высоких температур / Институт механики Уфимского научного центра РАН. - Уфа, 2013, том 51, № 4 - С. 543-551. Режим доступа: http://naukarus.com/k-teorii-rosta-parovyh -puzyrkov-v-metastabilnoy-zhidkosti

5. Актершев С. П. Моделирование вскипания метастабильной жидкости при наличии фронтов испарения [Электронный ресурс]/ С. П. Актершев, В. В. Овчинников // Современная наука: исследования, идеи, резуль- таты, технологии. - Днепропетровск: НПВК «Триакон», 2013. - Вып. 1 (12). - С. 77-82. - Режим доступа: http://modern.science.triacon.org/ru/issues/2013/files/paper s/1/77-82.pdf

6. Веретельник Т. И. Математическое моделирование кавитационного потока жидкости в химико-технологической системе / Т. И. Веретельник, Ю. Н. Дифучин; Черкасский государственный технологический университет // Вісник ЧДТУ, 2008. - № 3. - С. 82-85.

7. Кулинченко В. Р. Основы математического моделирования динамики роста паровой фазы [Электронный peсурс] / В. Р. Кулинченко; Национальный университет пищевых технологий. - 2012. - Режим доступа: http://dspace.nuft.edu.ua/jspui/handle/123456789/2224

8. Lambert J. D. Computational Methods in Ordinary Differential Equations / J. D. Lambert - Wiley, Chichester, 1991. - 304 p. - ISBN: 978-0-471-92990-1.

9. Butcher J. C. Numerical Methods for Ordinary Differential Equations / J. C. Butcher - New York: John Wiley \& Sons, 2008. - 482 p. - ISBN 978-0-470-72335-7.

Отримана в редакції 17.05.2017, прийнята до друку 06.06.2017

\title{
Analysis of Gas-Steam Bubbles Size Influence on the Hydrate Formation Process
}

\author{
B. Kutnyi ${ }^{1}$, A. Pavlenko ${ }^{2, \bigotimes}$, N. Abdullah ${ }^{3}$ \\ ${ }^{1,3}$ Poltava National Technical Yuri Kondratyuk University. 24 Pershotravnevyi ave., Poltava, 36011, Ukraine \\ ${ }^{2}$ Politechnika Świętokrzyska, aleja Tysiąclecia Państwa Polskiego 7, 25-314 Kielce, Polska \\ ORCID: ${ }^{1}$ 0000-0002-0548-7925, ${ }^{2}$ 0000-0002-8103-2578, ${ }^{3}$ 0000-0003-3922-0441; Scopus ID: ${ }^{2} 12801813400$ \\ $\triangle$ e-mail: am.pavlenko@i.ua
}

\begin{abstract}
A mathematical model that takes into consideration the inertial and thermodynamic components of bubbles oscillations, heat exchange processes in liquid, heat transfer on the boundary bubbles is proposed. Research of the gas-steam bubbles dynamic characteristics in various sizes has been carried out. After the performance of calculations graphs of the bubbles size change, its temperature, movement rate, steam environment pressure inside the bubble in time were built. It is established that each bubble size has its own oscillation frequency. The rate of hydrate formation has been calculated and it was established that it had maximum value during the heating of gas medium inside the bubbles. Gradually, in a viscous medium, the oscillations are damped and the hydrate formation process is maintained due to the removal of heat to the outer layers of the liquid. Based on the thermodynamic parameters of the contact surface of the liquid and gaseous phases, the amount of gas hydrate formed is determined. The results of the research can be used to optimize various technological processes associated with boiling, swelling of materials, formation of gas hydrates and cavitation in a liquid.
\end{abstract}

Key words: Mathematical Model; Bubble; Heat Exchange; Gas Hydrate; Pressure; Temperature.

\section{References}

1. KulInchenko, V. R., Zav'yalov, V. L., Misyura, T. G. (2007) Peredumovy stvorennia matematichnoi modeli osnovni polozhennia i rivnyannia ruhu Releia. Naukovi pratsi Natsionalnogo universytetu harchovyh tehnologii, No. 22, 36-41 (in Ukrainian)

2. Ilmov, D. N., Cherkasov, S. G. (2012) Teplofizicheskie protsessy pri szhatii parovogo puzyrka $\mathrm{v}$ zhidkom uglevo- dorode na osnove gomobaricheskoi modeli. Teplofizika vyisokih temperatur, 50(5), 676-684. URL: http://www.mathnet.ru/links/a96357749ddc8f7cc5ff3dcf53 c5493a/tvt396.pdf

3. Pavlenko, A. M., Koshlak, A. V. (2008) Osobennosti upravleniia protsessami formirovanika struktury i svoistv poristykh tel. Metallurgicheskaya teplotehnika, sbornik nauchnyih trudov NMet AU, 211-220 (in Russian) 
4. Shagapov, V. Sh., Koledin, V. V. (2013) K teorii rosta parovyh puzyrkov $\mathrm{v}$ metastabilnoi zhidkosti. Teplofizika vyisokih temperatur, 51(4), 543-551. URL: http://naukarus.com/k-teorii-rosta-parovyh-puzyrkov-vmetastabilnoy-zhidkosti

5. Aktershev, S. P., Ovchinnikov, V. V. (2013) Modelirovanie vskipaniia metastabilnoi zhidkosti pri nalichii frontov ispareniia. Sovremennaya nauka: issledovaniia, idei, rezultaty, tehnologii, 1 (12); 77-82. URL: http://modern.science.triacon.org/ru/issues/2013/files/paper s/1/77-82.pdf. (in Russian)

6. Veretelnik, T. I., Difuchin, Yu. N. (2008) Matematicheskoe modelirovanie kavitatsionnogo potoka zhidkosti v himiko-tehnologicheskoi sisteme. VIsnik ChDTU, No. 3, 82-85 (in Russian)
7. Kulinchenko, V. R. (2012) Osnovyi matematicheskogo modelirovaniia dinamiki rosta parovoy fazy. Natsionalnyiy universitet pischevyih tehnologiy. URL: http://dspace.nuft. edu.ua/jspui/handle/123456789/2224

8. Lambert, J. D. (1991) Computational Methods in Ordinary Differential Equations. Wiley, Chichester, 304 p. ISBN: 978-0-471-92990-1.

9. Butcher, J. C. (2008) Numerical Methods for Ordinary Differential Equations New York: John Wiley \& Sons, 482 p. ISBN 978-0-470-72335-7.

Received 17 May 2017 Approved 06 June 2017 Available in Internet 03 July 2017 